\title{
Role of Higher-"Mode" Pushover Analyses in Seismic Analysis of Buildings
}

\author{
Rakesh K. Goel, ${ }^{\text {a) }}$ M.EERI, and Anil K. Chopra, ${ }^{\text {b) }}$ M.EERI
}

\begin{abstract}
The role of higher-"mode" pushover analyses in seismic analysis of buildings is examined in this paper. It is demonstrated that the higher-"mode" pushover curves reveal plastic hinge mechanisms that are not detected by the first-"mode" or other FEMA-356 force distributions, but these purely local mechanisms are not likely to develop during realistic ground motions in an otherwise regular building without a soft and/or weak story. Furthermore, the conditions necessary for "reversal" of a higher-"mode" pushover curve are examined. It is shown that "reversal" in a higher-"mode" pushover curve occurs after formation of a mechanism if the resultant force above the bottom of the mechanism is in the direction that moves the roof in a direction opposite to that prior to formation of the mechanism. Such "reversal" can occur only in higher-"mode" pushover analyses but not in the pushover analyses for the first-"mode" or other FEMA-356 force distributions. However, the "reversal" in higher-"mode" pushover curves was found to be very rare in several recent investigations that examined behavior of many moment-resisting frame buildings. Included are guidelines for implementing the Modal Pushover Analysis for buildings that display "reversal" in a higher-"mode" pushover curve.
\end{abstract}

\section{INTRODUCTION}

The nonlinear static procedure (NSP) or pushover analysis, as described in FEMA356 (ASCE 2000) and ATC-40 (ATC 1997) documents, is now used by the structural engineering profession as a standard tool for estimating seismic demands and identifying plastic hinge mechanisms for buildings. It is now widely recognized that the standard NSP is applicable to low-rise buildings that respond primarily in the fundamental mode of vibration and have inelastic action that is uniformly distributed over the building height (Krawinkler and Seneviratna 1998).

Improved NSP to accurately estimate the seismic response of taller or irregular buildings have been developed. Among these are the NSP using adaptive-force distributions that follow the time-variant distribution of inertia forces (Bracci et al. 1997, Elnashai 2001, Gupta and Kunnath 2000), NSP that consider contribution of more than the

\footnotetext{
a) Professor, Department of Civil \& Environmental Engineering, California Polytechnic State University, San Luis Obispo, CA 93407; E-mail: rgoel@calpoly.edu

b) Johnson Professor, Department of Civil \& Environmental Engineering, University of California, Berkeley, CA 94720; E-mail: chopra@ce.berkeley.edu
} 
fundamental vibration mode (Chopra and Goel 2002, Goel and Chopra 2004, Jan et al. 2004, Kunnath and Gupta 2000, Matsumori et al. 1999, Sasaki et al. 1998), and incremental response spectrum analysis (Aydinoglu 2003).

Based on structural dynamics theory, the modal pushover analysis (MPA) procedure has been developed to include the higher-"mode" contributions to seismic demands (Chopra and Goel 2002). It estimated seismic demands much more accurately than FEMA-356 procedures for six SAC buildings (Goel and Chopra 2004) and 108 generic frames (Chopra and Chintanapakdee 2004).

In addition to estimating the seismic demands, such as story drifts and plastic hinge rotations, the nonlinear static procedures are also expected to provide insight into possible plastic hinge mechanisms of the building. The inability of the traditional NSP to correctly identify the location of plastic hinging was demonstrated based on postearthquake analysis of several buildings damaged during the 1994 Northridge earthquake (Islam et al. 1998, Sasaki et al. 1998) and by comparing its results with nonlinear response history analysis (Goel and Chopra 2004).

To identify plastic hinge mechanisms other than those revealed by first-"mode" or other FEMA-356 force distributions, pushover curves were developed using lateral force distributions corresponding to the first few elastic modes of the building (Sasaki et al. 1998). Based on analysis of a building damaged during the 1994 Northridge earthquake, it was found that the locations of plastic hinges revealed by the second-"mode" pushover analysis matched closely with the observed damage (Sasaki et al. 1998).

However, a recent investigation found that the roof displacement may reverse direction after initiation of yielding during a higher-"mode" pushover analysis (HernandezMontes et al. 2004). This phenomenon, denoted in this paper as "reversal" in the pushover curve, was found to occur during the third-"mode" pushover analysis of a threestory steel moment-resisting frame building.

The objectives of this paper are to (1) systematically identify local plastic hinge mechanisms revealed by higher-"mode" pushover analysis, (2) investigate whether these purely local mechanisms are likely to develop during realistic ground motions, (3) develop an understanding of conditions necessary for "reversal" of a higher-"mode" pushover curve, and (4) discuss procedures to estimate seismic demands for buildings that display reversal in higher-"mode" pushover curves.

\section{BUILDINGS CONSIDERED}

The building considered is the three-story steel building designed for Los Angles (Figure 1a) as part of the SAC project; details of this building are available elsewhere (Gupta and Krawinkler 1999, Hernandez-Montes et al. 2004). The SAC-Los Angeles three-story building has been selected for this investigation specifically because "reversal" in a higher-"mode" pushover curve was detected for this building (ATC 2003). This low-rise building has fairly uniform distribution of stiffness as well as strength throughout its height, without any obvious soft and/or weak story condition, and satisfies the 


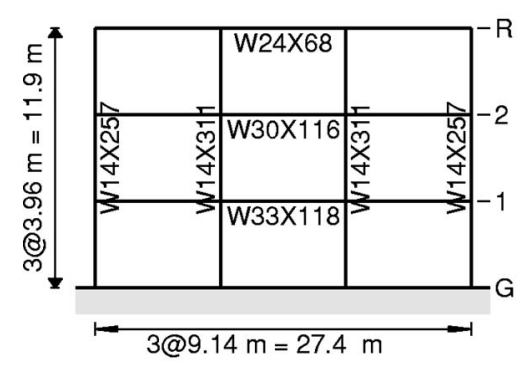

(a)

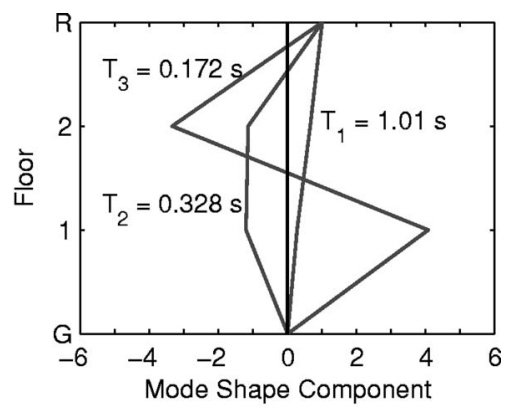

(b)

Figure 1. SAC-Los Angeles three-story building: (a) typical moment-resisting frame, and (b) first three natural vibration modes and periods.

FEMA-356 criterion for neglecting higher-"mode" effects. The first three modes of vibration and associated periods of the elastic building are shown in Figure $1 \mathrm{~b}$.

\section{PLASTIC MECHANISMS REVEALED BY PUSHOVER ANALYSES}

Figure 2 shows four FEMA-356 lateral force distributions-“Mode" 1, ELF, RSA, and Uniform-as well as "modal" lateral force distributions associated with the first three elastic modes. A detailed description of these lateral force distributions is available elsewhere (Goel and Chopra 2004). Note that all floors of the building are pushed in the same direction by FEMA-356 force distributions (Figure 2a), however, higher-"mode" force distributions pull some floors but push others (Figure 2b).

Each of the four force distributions in FEMA-356 leads to a "normal" pushover curve, i.e., the roof displacement increases monotonically in one lateral direction as the forces are increased (Figure 3a). Similarly, the first two "modal" pushover curves are "normal." However, "reversal" occurs in the third-"mode" pushover curve, i.e., the roof displacement reverses direction after initiation of yielding (Figure 3b).

The softening of the pushover curves noted in Figure 3 is associated with progressive formation of plastic hinges in the structural elements of the building with increasing lat-

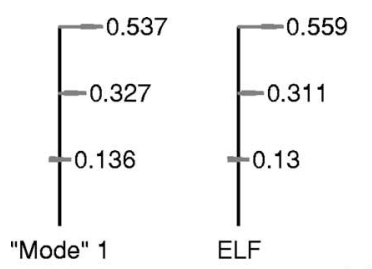

(a)

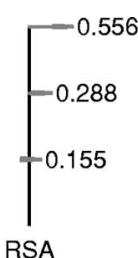

(a)

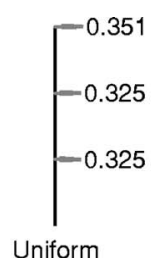

Uniform

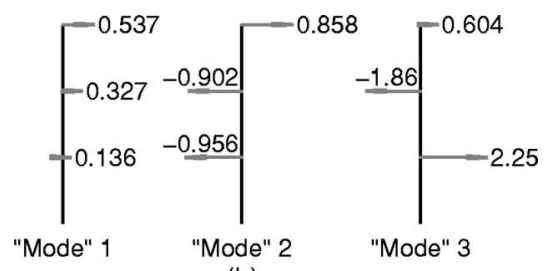

(b)

Figure 2. Height-wise distribution of lateral forces for the SAC-Los Angeles three-story building: (a) FEMA-356 distributions, and (b) "modal" force distributions. 


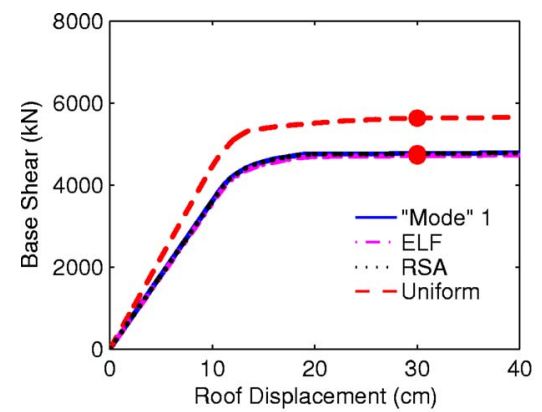

(a)

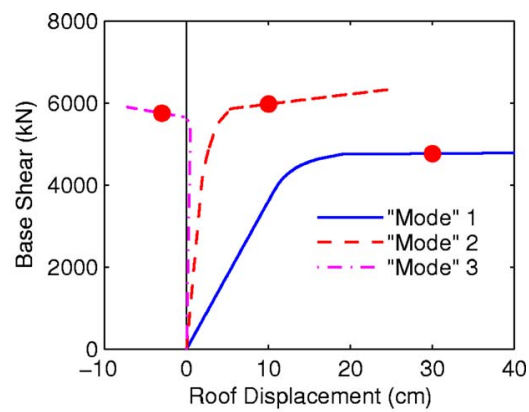

(b)

Figure 3. Pushover curves for SAC-Los Angeles three-story building: (a) FEMA-356 pushover curves, and (b) "modal" pushover curves. P-delta effects due to gravity loads are included.

eral forces. If the building is subjected to large enough forces, a plastic hinge mechanism forms and a small additional force causes a large increase in displacements, possibly leading to collapse.

Therefore, it is important to investigate possible plastic hinge mechanisms of the building, which are revealed by pushover analyses. For this purpose, Figure 4 presents plastic hinge locations due to FEMA-356 and "modal" force distributions at roof displacements shown in Figure 3 by solid circles on various pushover curves. The building, when pushed by each of the four FEMA-356 force distributions-"Mode" 1, ELF, RSA, and Uniform - develops plastic hinges at both ends of all beams and at the bottom of the first-story columns, representative of a global building mechanism (Figure 4a). However, higher-"mode" force distributions lead to entirely different plastic hinge mechanisms, which cannot be detected by any of the standard force distributions. When pushed by the second-"mode" force distribution, the building develops a local third-story mechanism: plastic hinges form at both ends of the beams at the roof level, and at the bottom of the top-story columns (Figure 4b). When pushed by the third-"mode" force distribution, the building develops a local second-story mechanism: plastic hinges form at the top and bottom of second-story columns (Figure 4c); these hinges form nearly simultaneously in all columns. Local mechanisms form during the second-and third-"mode" pushover

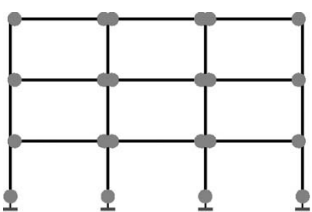

(a)

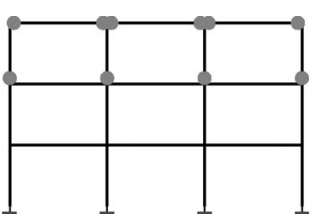

(b)

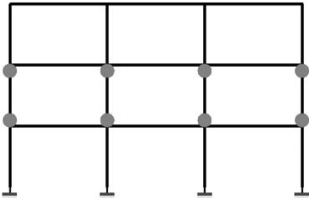

(c)

Figure 4. Mechanisms revealed by various force distributions: (a) FEMA-356 force distributions- "Mode" 1, RSA, ELF, and Uniform; (b) "Mode" 2 distribution; and (c) "Mode" 3 distribution. 
analyses even though the selected building does not have an obvious weak-or soft-story condition. The next section discusses the possibility of developing local plastic mechanisms revealed by higher-"mode" pushover analyses during earthquake excitations.

\section{RESPONSE TO EARTHQUAKE MOTIONS}

Dynamic response of the selected building to near-fault ground motions is computed by nonlinear Response History Analysis (RHA). Ground motions are described analytically (Mavroeidis and Papageorgiou 2003), where the ground velocity is defined as

$$
\dot{u}_{g}(t)=\left\{\begin{array}{c}
\dot{u}_{g o} \frac{1}{2}\left[1+\cos \left(\frac{2 \pi f_{p}}{\gamma}\left(t-t_{o}\right)\right)\right] \cos \left(2 \pi f_{p}\left(t-t_{o}\right)+v\right), \quad t_{o}-\frac{\gamma}{2 f_{p}} \leqslant t \leqslant t_{o}+\frac{\gamma}{2 f_{p}} \text { with } \gamma>1 \\
0, \quad \text { otherwise }
\end{array}\right.
$$

In this equation, a harmonic function of frequency $f_{p}$ is modulated by an elevated cosine function of frequency $f_{p} / \gamma$, and the product is defined over a limited duration; $\dot{u}_{g o}$ is the peak ground velocity, $T_{p}=1 / f_{p}$ is the period of the pulse; $\nu$ defines the phase of the harmonic, $\gamma$ defines the number of oscillations (i.e., zero crossings), and $t_{o}$ is the time instant at envelope's peak. Equation 1 has successfully modeled a wide range of nearfault ground motions (Mavroeidis and Papageorgiou 2003).

Computed is the response of the selected building to three ground motions defined by Equation 1, all with $\gamma=3$ and $\nu=180^{\circ}$ but different pulse period $T_{p}=T_{1}, T_{2}$, or $T_{3}$ and peak ground velocity, $\dot{u}_{g o}=50,60$, and $100 \mathrm{~cm} / \mathrm{sec}$. These ground velocities values of $\dot{u}_{g o}$ are well within the range of peak ground velocities for many near-fault ground motions (Mavroeidis and Papageorgiou 2003). The pulse periods $T_{2}=0.328 \mathrm{sec}$ and $T_{3}$ $=0.172 \mathrm{sec}$, however, which have been chosen only for illustration, are unrealistically small. Figures 5-7 present the time variation of the selected ground motion, the computed floor displacement response history, and displacement profile and plastic hinge locations at a selected time instant.

The first ground motion (Figure 5a) causes floor displacements that are nearly inphase throughout the duration of response and increase from the first floor to the roof (Figure 5b), and the displacement profile resembles the first "mode" (compare Figures $5 \mathrm{c}$ and $1 \mathrm{~b}$ ), indicating that the building responded primarily in the fundamental mode. All stories experienced significant inelastic action, as indicated by the permanent shift in the equilibrium positions of all floors immediately following the first large inelastic excursion (Figure 5b). The plastic hinge locations indicated a global mechanism (Figure $5 \mathrm{~d}$ ), which is identical to that predicted by the pushover analysis using first-"mode" or other FEMA-356 force distributions (see Figure 4a).

Response to the second ground motion (Figure 6a) indicates that, after the first halfsecond, the first and second floors vibrate essentially in-phase and the roof vibrates in opposite phase (Figure $6 \mathrm{~b}$ ) and the displacement profile resembles the second-"mode" shape (compare Figures $6 \mathrm{c}$ and $1 \mathrm{~b}$ ), indicating that the building responded primarily in the second "mode." Inelastic action was essentially confined to the third story, as indi- 

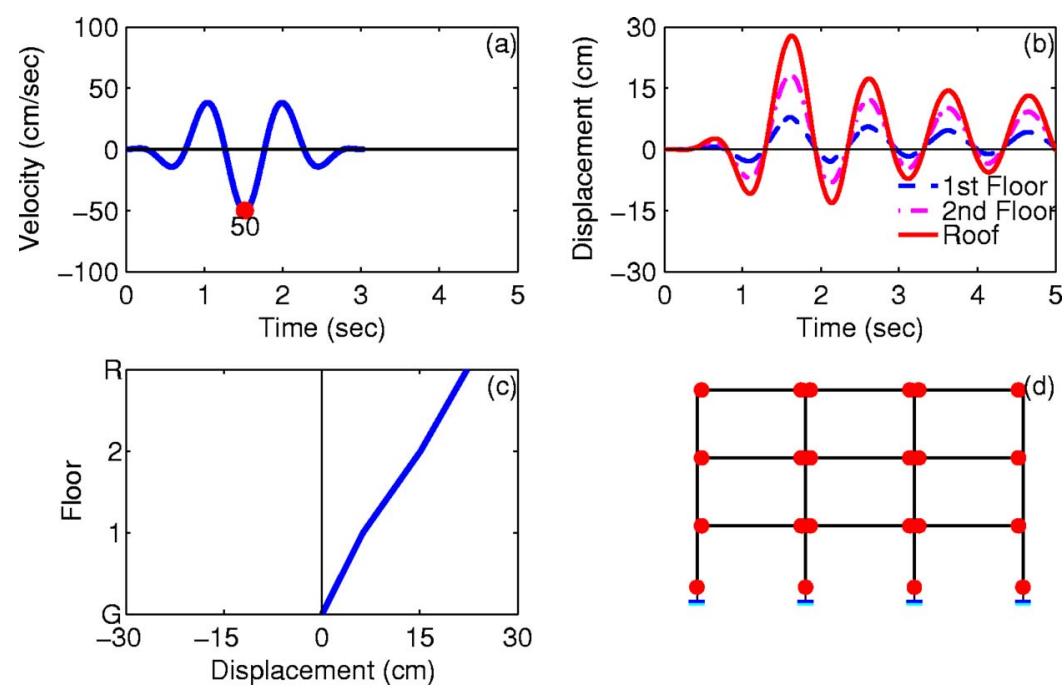

Figure 5. Response of the SAC-Los Angeles three-story building to near-fault (NF) ground motion: (a) NF excitation with $\dot{u}_{g o}=50 \mathrm{~cm} / \mathrm{sec}, T_{p}=T_{1}, \gamma=3$, and $\nu=180^{\circ}$; (b) history of floor displacements; (c) displacement profile at $1.5 \mathrm{sec}$; and (d) location of plastic hinges at $1.5 \mathrm{sec}$.
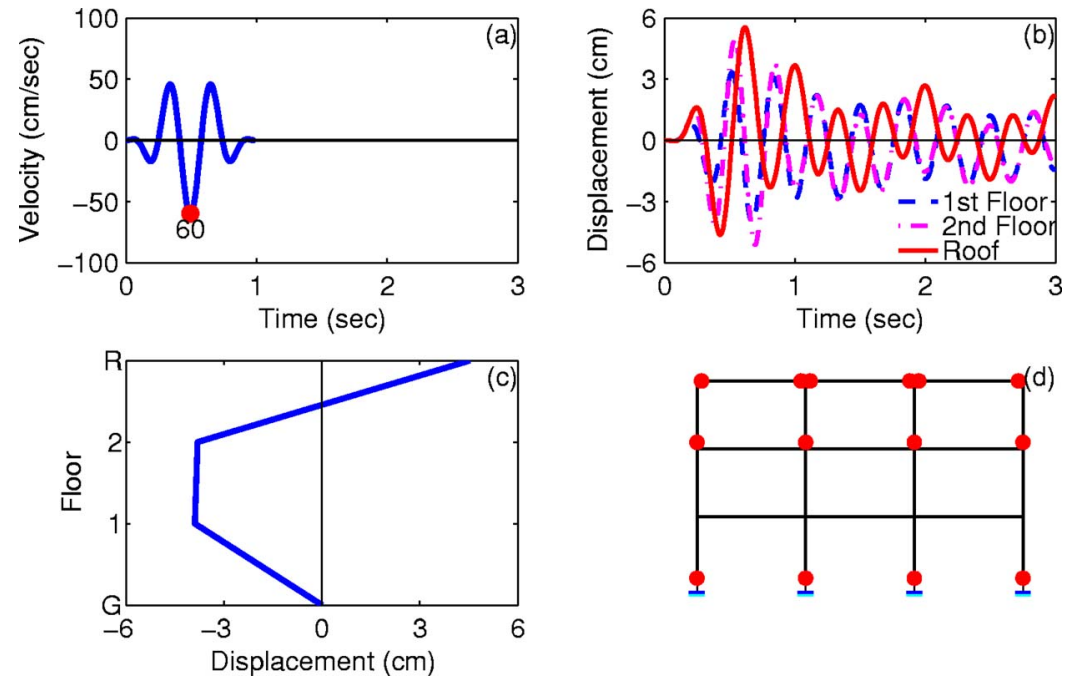

Figure 6. Response of the SAC-Los Angeles three-story building to NF ground motion: (a) NF excitation with $\dot{u}_{g o}=60 \mathrm{~cm} / \mathrm{sec}, T_{p}=T_{2}, \gamma=3$, and $\nu=180^{\circ}$; (b) history of floor displacements; (c) displacement profile at $0.66 \mathrm{sec}$; and (d) location of plastic hinges at $0.66 \mathrm{sec}$. 

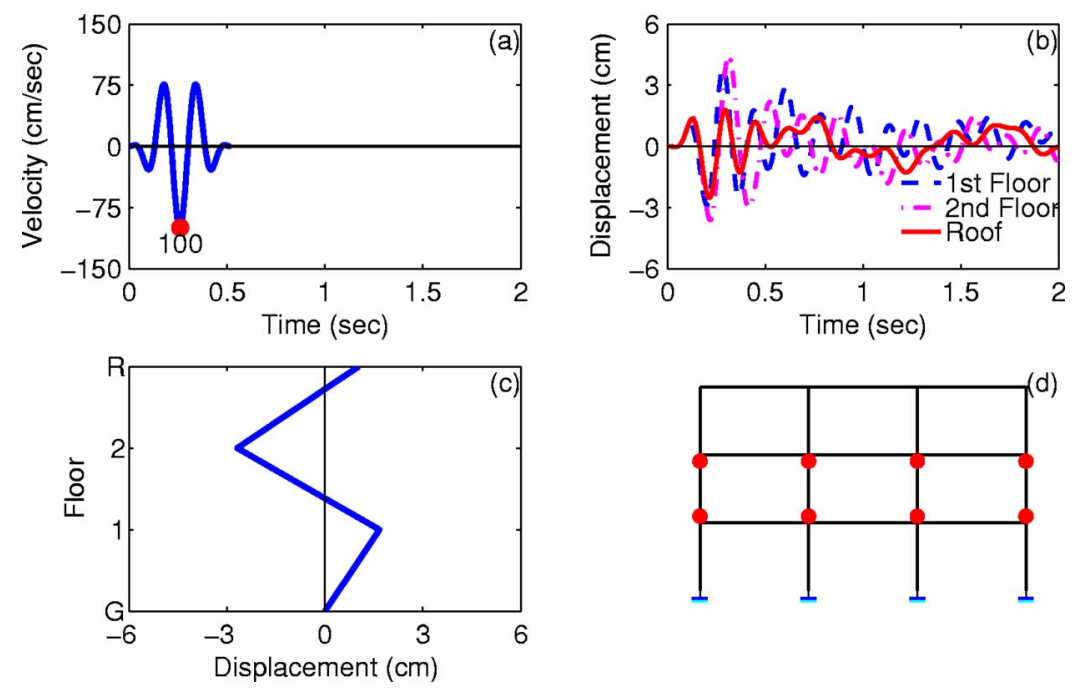

Figure 7. Response of the SAC-Los Angeles three-story building to NF ground motion: (a) NF excitation with $\dot{u}_{g o}=100 \mathrm{~cm} / \mathrm{sec}, T_{p}=T_{3}, \gamma=3$, and $\nu=180^{\circ}$; (b) history of floor displacements; (c) displacement profile at $0.435 \mathrm{sec}$; and (d) location of plastic hinges at $0.435 \mathrm{sec}$.

cated by the plastic hinge locations (Figure 6d), which are similar to the third-story mechanism predicted by the second-"mode" pushover analysis (see Figure 4b). Note that additional hinges at the base in Figure $6 \mathrm{~d}$ do not alter the third-story mechanism.

Response to the third ground motion (Figure 7a) indicates that, after the first quartersecond, the building vibrates primarily in the third "mode" (compare Figures 7c and 1b). Inelastic action is confined to the second story, as indicated by the plastic hinge locations (Figure 7d), which are similar to those in the second-story mechanism predicted by the third-"mode" pushover analysis (see Figure 4c).

The preceding results demonstrate that higher-"mode" pushover analysis identifies local mechanisms that are not detected by traditional pushover analysis using first"mode" or other FEMA-356 distributions, an observation made earlier (e.g., Islam et al. 1998, Sasaki et al. 1998). These local mechanisms can develop during ground motions with characteristics and intensity that excite the building into a higher "mode" beyond its elastic limit.

These purely local story mechanisms associated with a higher "mode" are possible, but are not likely to develop for most regular buildings, without a soft and/or weak story, during realistic ground motions. First, consider typical far-fault ground motions, which are broad-frequency-band excitations. Higher-"mode" pushover analysis and the associated plastic hinge mechanisms have been demonstrated to be important for estimating the seismic demands in upper stories of mid-rise and high-rise buildings (Goel and Chopra 2004). However, these mechanisms occur in conjunction with the first-"mode" global mechanism, which dominates building response. Next, consider far-fault motions 


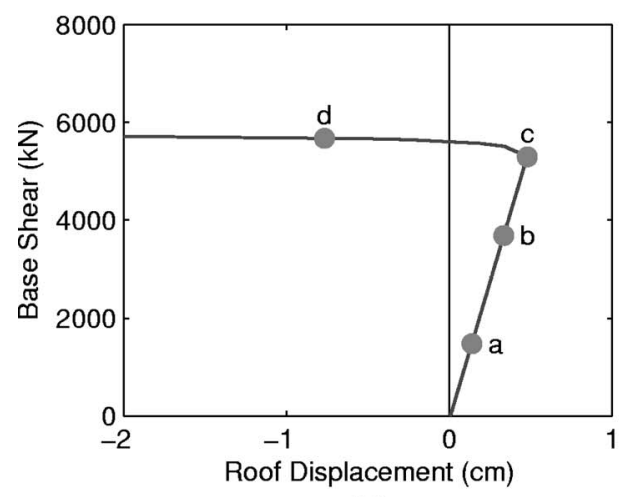

(a)

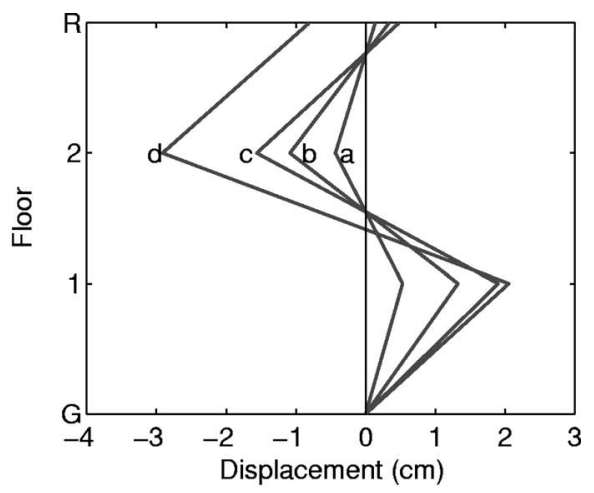

(b)

Figure 8. (a) Third-“mode" pushover curve, and (b) displacement profile of the building at four force levels during the pushover analysis.

recorded on sites with deep soft soil deposits, such as found in Mexico City and the San Francisco Bay margins. A local story mechanism associated with a higher "mode" may develop if the predominant period of these time-harmonic ground motions is close to the modal period, a scenario that is rare for known ground motions. For example, the predominant period of ground motions recorded at the SCT site in Mexico City is about 2 sec. Buildings with such a long higher-"mode" period are rare. Finally, consider nearfault (NF) ground motions. As demonstrated earlier, a local story mechanism associated with a higher "mode" may develop if the NF motion contains a forward directivity pulse with period close to a higher-"mode" vibration period, a scenario that is, again, rare for known ground motions. For example, the pulse period of NF motion recorded at the Los Gatos Presentation center during the 1989 Loma Prieta earthquake (magnitude 7.0) is $3.2 \mathrm{sec}$, and at the Jenson Filtration Plant during the 1994 Northridge earthquake (magnitude 6.7) is $3 \mathrm{sec}$ (see Mavroeidis and Papageorgiou 2003 for both values). Again, buildings with such a long higher-"mode" period are rare. However, purely local story mechanisms associated with a higher "mode" can develop during intense ground motions that are nearly harmonic with predominant period or are dominated by a distinct velocity pulse with pulse period close to the "modal" period.

\section{“REVERSAL" IN PUSHOVER CURVE}

Figure 8 shows the third-"mode" pushover curve and the displacement profile at four selected force levels identified by points $a, b, c$, and $d$. During the elastic stage of the pushover analysis (points $a, b$, and $c$ ), the deflected shape of the building is proportional to the third "mode" (compare displacement profiles $a, b$, and $c$ in Figure $8 \mathrm{~b}$ with the third-"mode" shape in Figure 1b), and the roof displacement increases in the positive direction as the force intensity increases. However, after the structure deforms beyond the elastic limit, a second-story mechanism forms (see Figure 4c), the deflected shape is 
no longer proportional to the third "mode," and the roof displacement reverses direction (Figure 8). This phenomenon, denoted as "reversal" in pushover curve, is examined in this section.

The behavior of the building described in the preceding paragraph can be explained based on elementary structural dynamics and plastic structural analysis. Recall that the modal pushover curve is developed by static analysis of the building for height-wise distribution of forces: $\mathbf{s}_{n}=f \mathbf{m} \boldsymbol{\phi}_{n}$ in which $\mathbf{m}$ is the mass matrix, $\boldsymbol{\phi}_{n}$ is the $n$th natural vibration mode, and $f$ is a scale factor. The natural vibration frequency $\omega_{n}$ and mode $\boldsymbol{\phi}_{n}$ are the solution of the eigenvalue problem for the elastic system:

$$
\mathbf{k} \boldsymbol{\phi}_{n}=\omega_{n}^{2} \mathbf{m} \boldsymbol{\phi}_{n}
$$

While the structure is in the elastic range during pushover analysis, the equation of static equilibrium in incremental form is

$$
\mathbf{k} \Delta \mathbf{u}=\Delta f \mathbf{m} \boldsymbol{\phi}_{n}
$$

The incremental displacements $\Delta \mathbf{u}$ can be determined by rearranging Equation 2:

$$
\mathbf{m} \boldsymbol{\phi}_{n}=\frac{1}{\omega_{n}^{2}} \mathbf{k} \boldsymbol{\phi}_{n}
$$

and substituting it in Equation 3 to obtain

$$
\Delta \mathbf{u}=\Delta f \frac{1}{\omega_{n}^{2}} \boldsymbol{\phi}_{n}
$$

which indicates that the incremental displacement due to $\Delta \mathbf{s}_{n}$ is proportional to the mode shape $\boldsymbol{\phi}_{n}$. As a result, the total deflected shape within the elastic range of the structure is also proportional to the mode shape.

Figure $8 \mathrm{~b}$ shows that the deflected shapes $a, b$, and $c$ of the building due to the third"mode" force distribution are proportional to the third-"mode" shape. Since the third "mode" is normalized such that the roof component is in the positive direction (see Figure 1b), the roof displacement continues to increase in the positive direction until the structure reaches its elastic limit (see point $c$ in Figure 8a).

After initiation of yielding, however, the deflected shape is no longer proportional to the mode shape and Equation 5 is no longer applicable because the incremental equation of static equilibrium,

$$
\mathbf{k}_{T} \Delta \mathbf{u}=\Delta f \mathbf{m} \boldsymbol{\phi}_{n}
$$

involves the tangent stiffness matrix $\mathbf{k}_{T}$, which is different than the elastic stiffness matrix $\mathbf{k}$ that appears in Equations 2 and 3.

Increasing the force intensity beyond level $c$ in Figure 8a, which results in a plastic mechanism in the second story and hence reduces the stiffness, causes an incremental displacement that is much larger than if the structure were still elastic. The building 


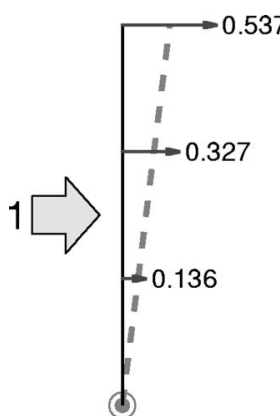

(a)

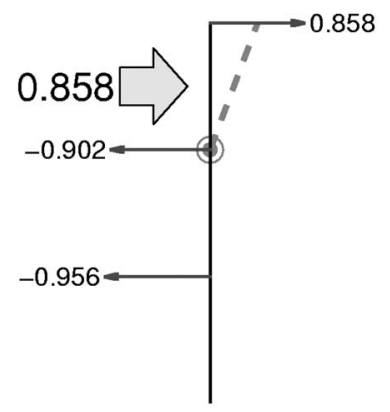

(b)

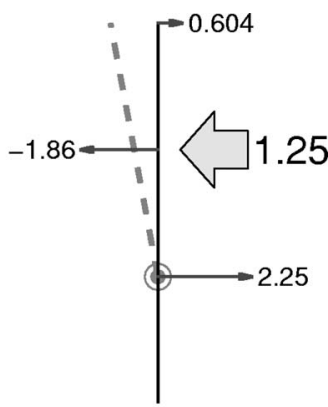

(c)

Figure 9. Resultant force and its direction above the base of the mechanism in the SAC-Los Angeles three-story building due to various "modal" distributions: (a) "Mode" 1, (b) "Mode" 2 , and (c) "Mode" 3.

above the first floor rotates counterclockwise as a rigid body about the first floor, the bottom of the mechanism (compare deflected shapes $c$ and $d$ in Figure 8b). The building rotates in the counterclockwise direction because the resultant force above the bottom of the mechanism acts to the left (see Figure 9c). Thus the roof, which at the lower force intensities (see deflected shapes at force levels $a$ to $b$ to $c$ in Figure 8b) moves to the right, reverses direction and moves to the left after formation of a mechanism (see deflected shape at force level $d$ in Figure 8b).

While the preceding discussion explains the phenomenon of "reversal" in the third"mode" pushover curve of the selected building, it is also useful to investigate the general conditions under which such "reversal" may or may not occur during pushover analysis for other modes. For this purpose, the resultant story forces above the mechanism bottom due to the other two "modal" force distributions are also included in Figure 9 , which schematically shows the bottom of the mechanism as a hinge and rotation of the building due to the resultant force by a thick dashed line.

The first-"mode" force distribution causes a global plastic mechanism (Figure 4a) and increasing force intensity will cause the building to rotate as a rigid body about its base, the bottom of the mechanism. The building will rotate in the clockwise direction because the resultant force acts to the right (Figure 9a). Thus the roof continues to move to the right in the same direction as in the elastic range (Figure 3b), and thus the pushover curve displays "normal" behavior without any "reversal" (Figure 3b). For similar reasons, "reversal" does not occur in the FEMA-356 pushover curves (Figure 3a).

The second-"mode" force distribution causes a local plastic mechanism in the third story (Figure 4b), and increasing force intensity will cause the third story to rotate as a rigid body about the second floor, the bottom of the mechanism. This story will rotate in the clockwise direction because the resultant force acts to the right (Figure 9b). Thus the 


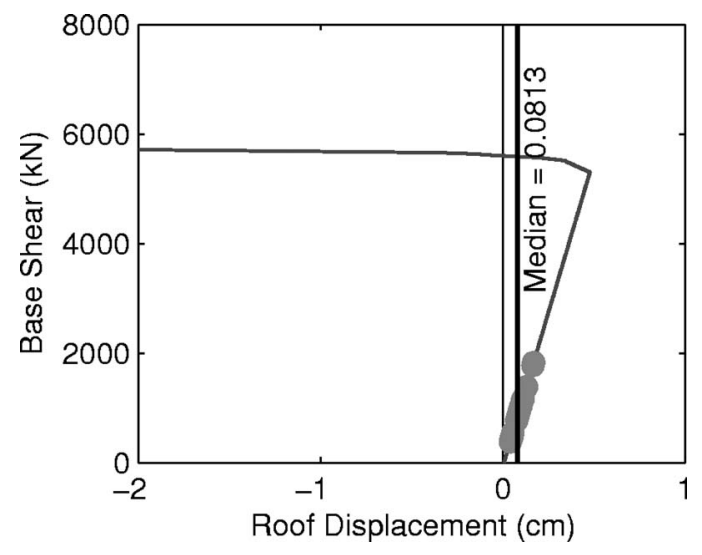

Figure 10. Third-"mode" pushover curve and the associated roof displacement of SAC-Los Angeles three-story building due to 2/50 set of ground motions.

roof continues to move to the right, the same direction as in the elastic range (Figure 3b), and thus the pushover curve displays "normal" behavior without any "reversal" (Figure $3 b)$.

In summary, "reversal" in the pushover curve occurs if a mechanism forms, and the resultant force above the bottom of the mechanism induces roof motion in the direction opposite to that prior to formation of the mechanism. Thus "reversal" in a pushover curve is a physically admissible phenomenon that can be explained based on fundamental principles of structural dynamics and plasticity theory.

\section{IMPLICATIONS FOR ESTIMATING SEISMIC DEMANDS}

The phenomenon of "reversal" in higher-"mode" pushover curves was found to be rare. It occurred only in four very low-strength, vertically irregular frames out of 108 generic frames analyzed by Chintanapakdee and Chopra (2003), and in two buildings investigated in the ATC-55 project (ATC 2003). Other investigations (Chopra and Goel 2004, Goel 2004, Goel and Chopra 2004) implemented higher-"mode" pushover analysis for several steel and concrete moment-resisting frame buildings, but did not encounter "reversal" in the pushover curve.

"Reversal" in a pushover curve is a potential impediment to application of the MPA procedure, as alluded to in a recent investigation (Hernandez-Montes et al. 2004). This difficulty may be avoided in three different ways. First, this issue is moot if the building does not deform beyond the elastic range during the design earthquake in the mode with "reversal" in the pushover curve. This is indeed the case for the SAC-Los Angeles threestory building considered in this investigation, which did not deform beyond the elastic limit in the third "mode" (Figure 10) due to any of the ground motions in the 2/50 set developed for the SAC study (Somerville et al. 1997), although these were very intense ground motions, which included several near-fault ground motions. The results pre- 


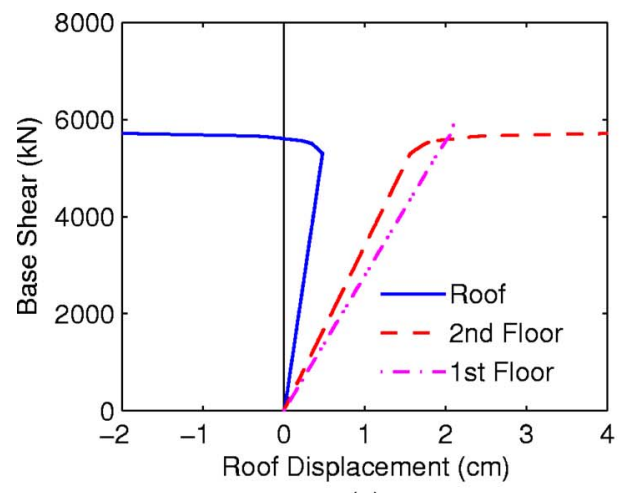

(a)

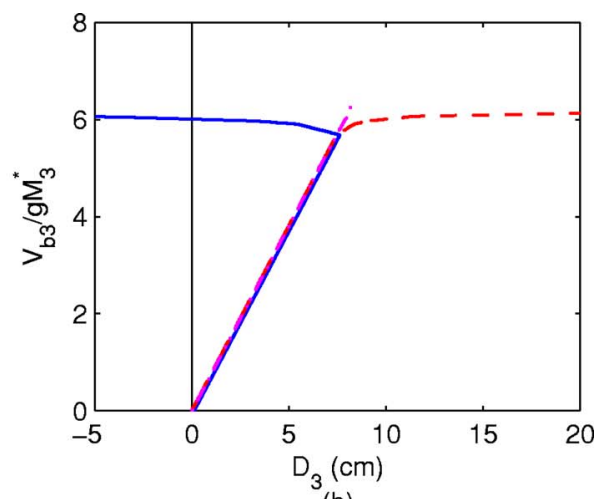

(b)

Figure 11. (a) Third-"mode" pushover curve: base shear plotted against each floor displacement, and (b) force deformation relation for third-"mode" inelastic SDF system.

sented in Figure 10 include the third-"mode" pushover curve, which exhibits "reversal," and the roof displacement of the building in the third "mode." Clearly, the peak deformations due to individual ground motions (shown in solid circles on the pushover curve) as well as median value are well below the elastic limit.

Second, because inelastic action in higher "modes" is usually limited, seismic demands may be estimated by the modified MPA procedure (ATC 2003, Chopra et al. 2004) in which the seismic demands associated with higher "modes" are calculated assuming that the building remains elastic, thus eliminating the need for higher-"mode" pushover analysis. This modified MPA is an attractive alternative for practical application because it leads to a larger estimate of seismic demands, thus reducing the unconservatism (relative to nonlinear RHA) of MPA results in some cases and increasing their conservatism in others. While this increase in demand is modest and acceptable for systems with moderate damping, around $5 \%$, it is unacceptably large for lightly damped systems, e.g., SAC buildings (Chopra et al. 2004).

Third, any "reversal" of the traditional pushover curve (Figure 8a) that plots base shear versus roof displacement, may be eliminated if another floor displacement is used as the reference displacement. This possibility is demonstrated in Figure 11a showing the base shear plotted against each of the floor displacements for the SAC-Los Angeles three-story building. "Reversal" in the pushover curve using roof displacement is eliminated in the base shear plot against the second-floor displacement. Although "reversal" is also avoided when the first-floor displacement is selected as the reference displacement, this pushover curve is not meaningful. It remains linear in spite of the plastic hinge mechanism in the second story, implying that the reference displacement must be chosen at a floor above the yielded stories of a building.

Converting the pushover curves in Figure 11a to the force-deformation relation for the third-"mode" inelastic SDF system by obvious extensions of existing concepts (e.g., Chopra and Goel 2004) leads to Figure 11b. As expected, the elastic stiffness of the three 
curves is identical, equal to the square of the modal frequency. The post-yield behavior is defined meaningfully only by the curve using the second-floor displacement as the reference displacement. This pushover curve is usable in the MPA procedure to include contributions of this "mode" to the seismic demands.

\section{CONCLUSIONS}

This investigation on higher-"mode" pushover analysis has led to the following conclusions:

1. Higher-"mode" pushover analyses reveal local story mechanisms not detected by the traditional pushover analysis using first-"mode" or other FEMA-356 distributions, as also demonstrated in earlier publications.

2. Although higher-"mode" pushover analyses and the associated plastic mechanisms are important in estimating the seismic demands for many buildings, these purely local story mechanisms, although possible, are not likely to develop in most regular buildings without obvious soft and/or weak story conditions during realistic ground motions.

3. "Reversal" in a higher-"mode" pushover curve occurs after formation of a mechanism if the resultant force above the mechanism is in the direction that moves the roof in a direction opposite to that prior to formation of the mechanism. Such "reversal" can occur only in pushover curves for "modes" higher than the fundamental mode, and not in the pushover curves for first-"mode" or other FEMA-356 force distributions. The phenomenon of "reversal" in higher"mode" pushover curves was found to be very rare in several recent investigations that examined behavior of steel and concrete moment-resisting frame buildings.

4. The difficulties associated with implementation of the MPA procedure-a procedure that explicitly considers effects of higher "modes" through higher"mode" pushover analyses - may be avoided in three different ways. First, this issue is moot if the building does not deform beyond the elastic range during the design earthquake in the mode with "reversal" in the pushover curve; this is often the case. Second, seismic demands may be estimated by the modified MPA procedure (Chopra et al. 2004) in which the seismic demands associated with higher "modes" are calculated assuming that the building remains elastic. Third, any "reversal" of the traditional pushover curve may be eliminated by plotting base shear against the displacement of a different floor above the yielded stories of the building. The resulting pushover curve is usable in the MPA procedure.

\section{ACKNOWLEDGMENTS}

This research investigation is funded by the National Science Foundation under Grant CMS-9812531, a part of the U.S.-Japan Cooperative Research in Urban Earthquake Disaster Mitigation; this financial support is gratefully acknowledged. This investigation was prompted by discussions with some of the ATC-55 project personnel, in particular, Mark Aschheim, who detected unusual behavior in higher-"mode" pushover 
analysis of the three-story building considered here. Dr. Aschheim's review of an early draft helped to improve the manuscript, for which we are grateful. Comments from the anonymous reviewers and, especially, the responsible editor, also helped in significantly improving the manuscript.

\section{REFERENCES}

American Society of Civil Engineers (ASCE), 2000. Prestandard and Commentary for the Seismic Rehabilitation of Buildings, prepared for the SAC Joint Venture, published by the Federal Emergency Management Agency, Report No. FEMA-356, Washington, D.C.

Applied Technology Council (ATC) 1997. Seismic Evaluation and Retrofit of Concrete Buildings, prepared for the Seismic Safety Commission, State of California, Report No. ATC-40, Redwood City, CA.

Applied Technology Council (ATC), 2003. Improvement of Inelastic Seismic Analysis Procedures, (FEMA-440), October 2003 Draft of Report No. ATC-55, developed by the ATC-55 Project, Redwood City, CA.

Aydinoglu, M. N., 2003. An incremental response spectrum analysis procedure based on inelastic spectral displacements for multi-mode seismic performance evaluation, Bulletin of Earthquake Engineering 1 (1), 3-36.

Bracci, J. M., Kunnath, S. K., and Reinhorn, A. M., 1997. Seismic performance and retrofit evaluation for reinforced concrete structures, J. Struct. Eng. 123 (1), 3-10.

Chintanapakdee, C., and Chopra, A. K., 2003. Evaluation of Modal Pushover Analysis Procedure Using Vertically "Regular" and "Irregular" Generic Frames, Report No. UCB/EERC2003/02, Earthquake Engineering Research Center, University of California, Berkeley.

Chopra, A. K., and Goel, R. K., 2002. A modal pushover analysis procedure for estimating seismic demands for buildings, Earthquake Eng. Struct. Dyn. 31 (3), 561-582.

Chopra, A. K., and Goel, R. K., 2004. A modal pushover analysis procedure to estimate seismic demands for unsymmetric-plan buildings, Earthquake Eng. Struct. Dyn. 33 (8), 903-927.

Chopra, A. K., Goel, R. K., and Chintanapakdee, C., 2004. Evaluation of a modified MPA procedure assuming higher modes as elastic to estimate seismic demands, Earthquake Spectra 20 (3), 757-778.

Chopra, A. K., and Chintanapakdee, C., 2004. Comparative evaluation of FEMA and modal pushover analyses: Vertically regular and irregular generic frames, Earthquake Spectra 20 (1), 255-271.

Elnashai, A. S., 2001. Advanced inelastic static (pushover) analysis for earthquake applications, Struct. Eng. Mech. 12 (1), 51-69.

Goel, R. K., 2004. Evaluation of modal and FEMA pushover procedures using strong-motion records of buildings, Earthquake Spectra 21 (3), 653-684.

Goel, R. K., and Chopra, A. K., 2004. Evaluation of modal and FEMA pushover analyses: SAC buildings, Earthquake Spectra 20 (1), 225-254.

Gupta, A., and Krawinkler, H., 1999. Seismic Demands for Performance Evaluation of Steel Moment Resisting Frame Structures (SAC Task 5.4.3), Report No. 132, John A. Blume Earthquake Engineering Center, Stanford, CA.

Gupta, B., and Kunnath, S. K., 2000. Adaptive spectra-based pushover procedure for seismic evaluation of structures, Earthquake Spectra 16 (2), 367-392. 
Hernandez-Montes, E., Kwon, O.-S., and Aschheim, M. A., 2004. An energy-based formulation for first- and multiple-mode nonlinear static (pushover) analyses, J. Earthquake Eng. 8 (1), 69-88.

Islam, M. S., Gupta, B., and Kunnath, S. K., 1998. A critical review of state-of-art analytical tools and acceptance criterion in light of observed response of an instrumented nonductile concrete frame building, Proceedings, 6th U.S. National Conference on Earthquake Engineering, Seattle, Wash.

Jan, T. S., Liu, M. W., and Kao, Y. C., 2004. An upper-bound pushover analysis procedure for estimating the seismic demands of high-rise buildings, Eng. Struct. 26 (1), 117-128.

Krawinkler, H., and Seneviratna, G., 1998. Pros and cons of a pushover analysis of seismic performance evaluation, Eng. Struct. 20 (4-6), 452-464.

Kunnath, S. K., and Gupta, B., 2000. Validity of deformation demand estimates using nonlinear static procedures, Proceedings, U.S.-Japan Workshop on Performance-Based Engineering for Reinforced Concrete Building Structures, Sapporo, Hokkaido, Japan.

Matsumori, T., Otani, S., Shinohara, H., and Kabeyasawa, T., 1999. Earthquake member deformation demands in reinforced concrete frame structures, Proceedings, U.S.-Japan Workshop on Performance-Based Earthquake Engineering Methodology for RC Building Structures, Maui, Hawaii.

Mavroeidis, G. P., and Papageorgiou, A. S., 2003. A mathematical representation of near-fault ground motions, Bull. Seismol. Soc. Am. 93 (1), 1099-1131.

Sasaki, K. K., Freeman, S. A., and Paret, T. F., 1998. Multimode pushover procedure (MMP) - A method to identify the effects of higher modes in a pushover analysis, Proceedings, 6th U.S. National Conference on Earthquake Engineering, Seattle, Wash.

Somerville, P., Smith, N., Punyamurthula, S., and Sun, J., 1997. Development of Ground Motion Time Histories for Phase 2 of the FEMA/SAC Steel Project, Report No. SAC/BD-9/04, SAC Background Document, SAC Joint Venture, Sacramento, CA. 